\title{
Acknowledgements
}

I am indebted to Bart Moore-Gilbert and Robert Clark for their support and advice at all stages of this project; without their valued input this book would not exist. I am also grateful to all those who commented on sections of the work in progress, particularly John Thieme, my series editor, and Margaret Coxall, who read most of the draft manuscript and who distracted me by noticing Rushdie's fascination with nipples. Thanks must also go to a small but invaluable band of fellows: to Christopher Warne for keeping me company with his book on Aristotle, to Anna Johnson for parachuting in from Tasmania with 'tales from the archives', to Mum and John for their unfailing confidence, to Max Coxall for his unhesitating generosity, to Brenda and Andrew for consistently finding exquisite holiday locations for me to work in, to Marie and Michael for finding argumentative friends with strong opinions about Rushdie, to Jade and May for entertaining Dom, and to Ada for 'not annoying Tev' with a butterfly net in the early stages. My supreme thanks is reserved for Simone, Dominic and Tristan. The latter two were forced to share their first months and years with this book and so deserve some recompense. The former has made everything possible by supplying generous quantities of patience, encouragement, intellectual inspiration, emotional reinforcement and red wine. This book is for them.

Quotations from Imaginary Homelands: Essays and Criticism, 1981-1991 by Salman Rushdie, copyright (C) 1991 by Salman Rushdie, are used by permission of Penguin Books Ltd, and Viking Penguin, a division of Penguin Group (USA) Inc. Quotations from Salman Rushdie Interviews: A Sourcebook of His Ideas, ed. Pradyumna S. Chauhan, copyright (C) 2001 by Pradyumna S. Chauhan, are reproducted with permission of Greenwood Publishing Group, 


\section{xii Acknowledgements}

Inc., Westport, CT. Lines from Sujata Bhatt's 'A Different History', Brunizem copyright (C) 1988 Sujata Bhatt are reproduced with permission of Carcanet Press. 